\title{
Littler Flap: A reliable option in soft tissue defects of different fingers
}

\section{Littler Flep: Farklı parmakların yumuşak doku defektlerinde güvenilir bir seçenek}

Ali Rıza Yıldırım, Murat İğde, Mehmet Tapan, Mehmet Onur Öztürk, Burak Yaşar, Ramazan Erkin Ünlüi

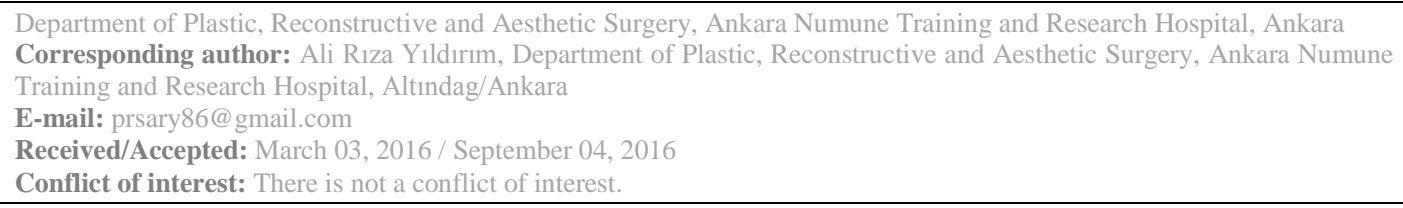

\section{SUMMARY}

Objective: Finger soft tissue defects are common following trauma, burn, and contracture release. Heterodigital neurovascular island flap is one of the important flaps used for this purpose. However, it is generally used for the repair of pulp defects involving first finger, it is also useful for defects involving other fingers. In this study, we presented our clinical findings on the use of and outcomes associated with Littler flap in the reconstruction of soft tissue defects involving not only first finger, but also different fingers.

Method: This descriptive study included 13 patients ( 9 males, 4 females) who were treated with a neurovascular island flap for different finger soft tissue defect between August 2012 and June 2014. Tissue defect was located the thumb in 4 patients, index finger in 4 patients, middle finger in 3 patients and ring finger in 2 patients. We evaluated sensibility and range of motion of the injured finger and donor finger.

Results: In the study group, all flaps survived completely. At a mean follow-up of 12 months, the results of the donor and reconstructed fingers regarding range of motion showed that all patients achieved excellent or good results. The donor-site morbidity was accepted. The patients rarely complained of pain or the cold intolerance of the flap.

Conclusions: The most important reason for the preference given to this flap in the reconstruction of finger defects is a reliable option due to constant pedicle for flap viability, single stage procedure, early mobilization of the hand, good functional and cosmetic result. Our opinion is that a littler flap should be used in different finger defects since it is highly useful and reliable in terms of flap complications and donor field morbidities.

Keywords : finger injuries, island flaps , pedicled flap, soft tissue injuries 
Amaç: Travma, yanık ve kontraktür açılmasını takiben parmak yumuşak doku defektleri sıktır. Heterodijital nörovasküler ada flebi, bu amaçla kullanılan önemli fleplerden biridir. Genellikle birinci parmak pulpa defektlerinin tamirinde kullanılmasına rağmen diğer parmaklarda oluşan defektleri için de kullanışlı bir seçenektir. Bu çalışmada sadece 1.parmakta değil farklı parmak yumuşak doku defektlerinin rekonstrüksiyonunda littler flebi kullanımı ve sonuçları sunulmuştur.

Yöntem: Bu tanımlayıcı çalışmada, Ağustos 2012- Haziran 2014 tarihleri arasında nörovasküler ada flebi ile parmak yumuşak doku defekti rekonstrüksiyonu uygulanan 13 hasta (9 erkek, 4 kadın) çalışmaya dahil edilmiştir. Doku defekti, 4 hastanın başparmağında, 4 hastanın işaret parmağında, 3 hastanın orta parmağında, 2 hastanın da yüzük parmağında yer almaktaydı. Donor ve yaralanan parmaklar, hareket açıklı̆̆ı ve duyu açısından değerlendirildi.

Bulgular: $\mathrm{Bu}$ çalı̧̧ma grubunda, fleplerin tamamı yaşadı. Ortalama 12 ay takipte, donor ve rekonstrükte edilen parmakların hareket açıklığına göre sonuçları tüm hastalarda mükemmel yada iyi olarak gösterildi. Donor saha morbiditesi kabul edilebilirdi. Hastalar, nadiren ağr1 ve soğuk intoleransından yakınmaktaydı.

Sonuç: Parmak defektlerinin rekonstrüksiyonunda bu flebin tercih edilmesinin en önemli nedeni, flep yaşayabilirliği için sabit pedikülü olması, tek aşamalı prosedür olması, elin erken hareketi, iyi fonksiyonel ve kozmetik sonuç nedeniyle uygun bir seçenektir. Bizim düşüncemiz, littler flep, donor saha morbiditesi ve flep komplikasyonları açısından son derece kullanışlı ve uygun olmasından dolayı, farklı parmak defektlerinde kullanılmalıdır.

Anahtar sözcükler: parmak yaralanmaları, pediküllü flep, yumuşak doku yaralanmaları

\section{INTRODUCTION}

Finger soft tissue defects are common following trauma, burns, and contracture release, as well as due to secondary causes after a primary operation. Various local pedicled flaps or island flaps are preferred for the reconstruction of finger soft tissue defects. Early stage reconstruction is very important to prevent complications such as stiff finger and flexion contracture due to scar formation. ${ }^{1}$ A flap with sensory capacity are particularly preferable in defects involving finger pulp. Furthermore, in defects accompanying injuries to some important anatomic structures such as tendon, vessel, or nerve, it is important to cover the defect as soon as possible and at a single stage, begin rehabilitation, and shorten time to return work.

Neurovascular island flap was first used by Bunnel in 1931 to reconstruct a defect in a thumb amputation stump using a neurovascular flap with sensory capacity elevated from the adjacent finger. Starting from the modifications made by Moberg and Littler, neurovascular island flaps for thumb defects have begun to be elevated from the ulnar half of the fourth finger (Figure 1). ${ }^{2}$ In this study, we presented our clinical results of the Littler flap which was used for thumb, index finger, middle finger and ring finger.
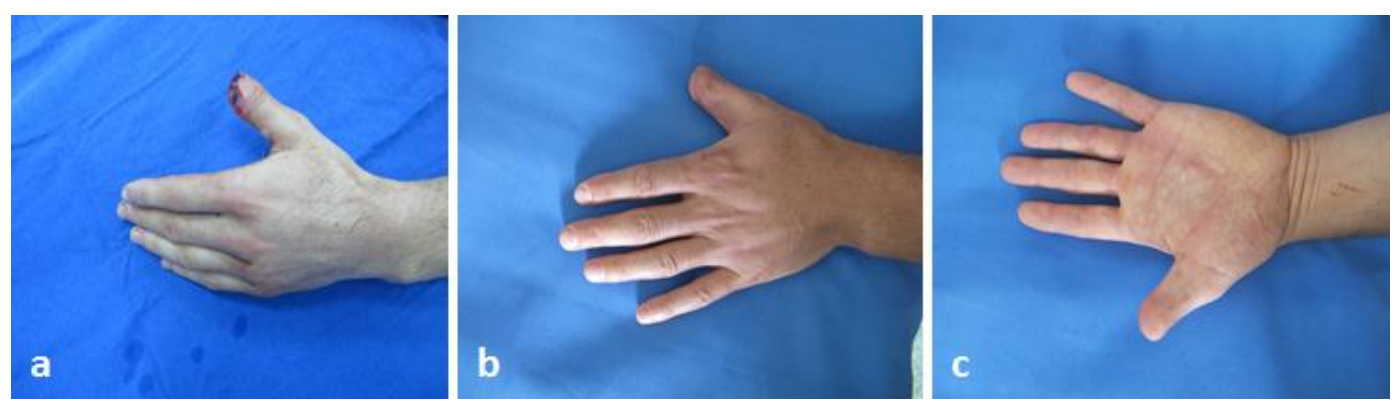

Figure 1. A sample case of classic littler flap. a) An exposing bone defect of the first finger. Flap was harvested from the ulnar side of ring finger. b) Dorsal view postoperative at 3 month, c) Volar view postoperative at 3 month 


\section{MATERIAL AND METHODS}

This descriptive study included all patients (9 males, 4 females) who were treated with a neurovascular island flap for a finger soft tissue defect between August 2012 and June 2014. The mean age of the study population was 37 (20$67)$ years. Thirteen finger injuries were treated in 13 patients. The injury was a sharp penetrating object injury in 4 patients, crush injury in 6 patients, burn injury in 2 patients, and a defect remaining after contracture release in a patient (Table 1).

Tissue defect was located the thumb in 4 patients, index finger in 4 patients, middle finger in 3 patients, and ring finger in 2 patients (Figure 2). Ring finger was preferred as the donor area for flaps to be used for soft tissue defects in 10 patients and middle finger in additional 3 patients. Ten flaps were elevated from the lateral aspect of the ulnar side of ring finger whereas flaps were elevated from the lateral aspect of the ulnar side of middle finger due to a scar in ring finger from a previous operation or injury in 3 patients. Mean defect size was $2.3 \mathrm{~cm}^{2}\left(1.5-3.2 \mathrm{~cm}^{2}\right)$. The longitudinal and transverse axis of the planned flaps were measured $2.1 \mathrm{~cm}$

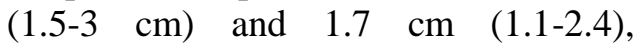
respectively.

The operations were performed under general anesthesia or axillary block using a pneumatic tourniquet. The flap was elevated from ulnar aspect of the ring or middle finger. The flap extends from finger tip to the proximal interphalangeal (PIP) joint. Flap elevation proceeds from distal to proximal, pedicled on the corresponding neurovascular bundle. A zigzag insicion was performed from distal palmar crease to proximal of the flap. The perivascular fatty tissue was preserved for better venous drainage. The flaps were transferred to recipient area a tunnelized pedicle all patients. Donor area was primarily reconstructed in 3 patients and closed with a full-thickness skin graft in 10 patients. The patients were monitored for flap circulation for 3 (2-6) days after the operation. They were then followed regularly for about a mean follow-up of 12 (9-16) months.

The following parameters were assessed: active range of motion of the distal interphalangeal joint and proximal interphalangeal joint for both the reconstructed and donor fingers, sensation of the flap and donor site. The range of motion of the proximal and distal interphalangeal joints of the reconstructed and donor fingers were measured by a goniometer at postoperative follow-up. The motion arcs of the fingers were compared with the normal hand. The sensibility of the flaps and donor sites was measured with the Semmes-Weinstein monofilament test and the static 2-point discrimination (2PD) test as well as cold intolerance test. ${ }^{3,4}$ Two point discrimination measurements were done according to the Modified Criteria of the American Society for Surgery of the Hand (excellent $<6 \mathrm{~mm}$, good 6-10 $\mathrm{mm}$, moderate $11-15 \mathrm{~mm}$, and poor $>15 \mathrm{~mm}$ ). Cold intolerance in both injured and normal finger was categorized as mild, moderate, severe, and very severe (0-25, 26-50, 51-75, 76-100, respectively), based on the Cold Intolerance Severity Score Questionnaire. ${ }^{5,6}$

The pain of the reconstructed finger and the donor site was given subjectively by the patient using the visual analogue scale, which ranged from 0 to $10(0-$ no pain and 10 - worst pain).

According to the Michigan Hand Outcomes Questionnaire, patients reported their satisfaction with the appearance of the injured hand The questions were based on a five-point response scale. ${ }^{7}$ Descriptive statistics analysis were performed using the statistical software SPSS version 16.0 software (SPSS Inc, Chicago, III, USA). Data were expressed as frequency. 
Table 1. Patients and characteristics.

\begin{tabular}{|l|l|l|l|l|l|l|}
\hline $\begin{array}{l}\text { Case } \\
\text { No. }\end{array}$ & Age & Sex & Injury Finger & $\begin{array}{l}\text { Donor } \\
\text { finger }\end{array}$ & Complication & $\begin{array}{l}\text { Follow-up } \\
\text { (mo) }\end{array}$ \\
\hline $\mathbf{1}$ & 20 & M & Distal phalanx of the thumb & Ring & - & 11 \\
\hline $\mathbf{2}$ & 28 & M & Middle phalanx of the index & Middle & - & 13 \\
\hline $\mathbf{3}$ & 23 & M & Distal phalanx of the index & Ring & Venous congestion & 10 \\
\hline $\mathbf{4}$ & 31 & F & $\begin{array}{l}\text { Proximal phalanx of the } \\
\text { middle }\end{array}$ & Ring & - & 10 \\
\hline $\mathbf{5}$ & 27 & M & Distal phalanx of the index & Ring & Venous congestion & 12 \\
\hline $\mathbf{6}$ & 30 & F & Distal phalanx of the thumb & Ring & - & 15 \\
\hline $\mathbf{7}$ & 44 & F & Middle phalanx of the index & Ring & - & 16 \\
\hline $\mathbf{8}$ & 52 & M & $\begin{array}{l}\text { Middle phalanx of the } \\
\text { middle }\end{array}$ & Ring & - & 12 \\
\hline $\mathbf{9}$ & 56 & M & Distal phalanx of the thumb & Ring & - & 14 \\
\hline $\mathbf{1 0}$ & 40 & F & $\begin{array}{l}\text { Proximal phalanx of the } \\
\text { ring }\end{array}$ & Middle & Venous congestion & 10 \\
\hline $\mathbf{1 1}$ & 32 & M & Distal phalanx of the ring & Middle & - & 12 \\
\hline $\mathbf{1 2}$ & 67 & M & Distal phalanx of the thumb & Ring & - & 9 \\
\hline $\mathbf{1 3}$ & 33 & M & Distal phalanx of the middle & Ring & - & 12 \\
\hline
\end{tabular}
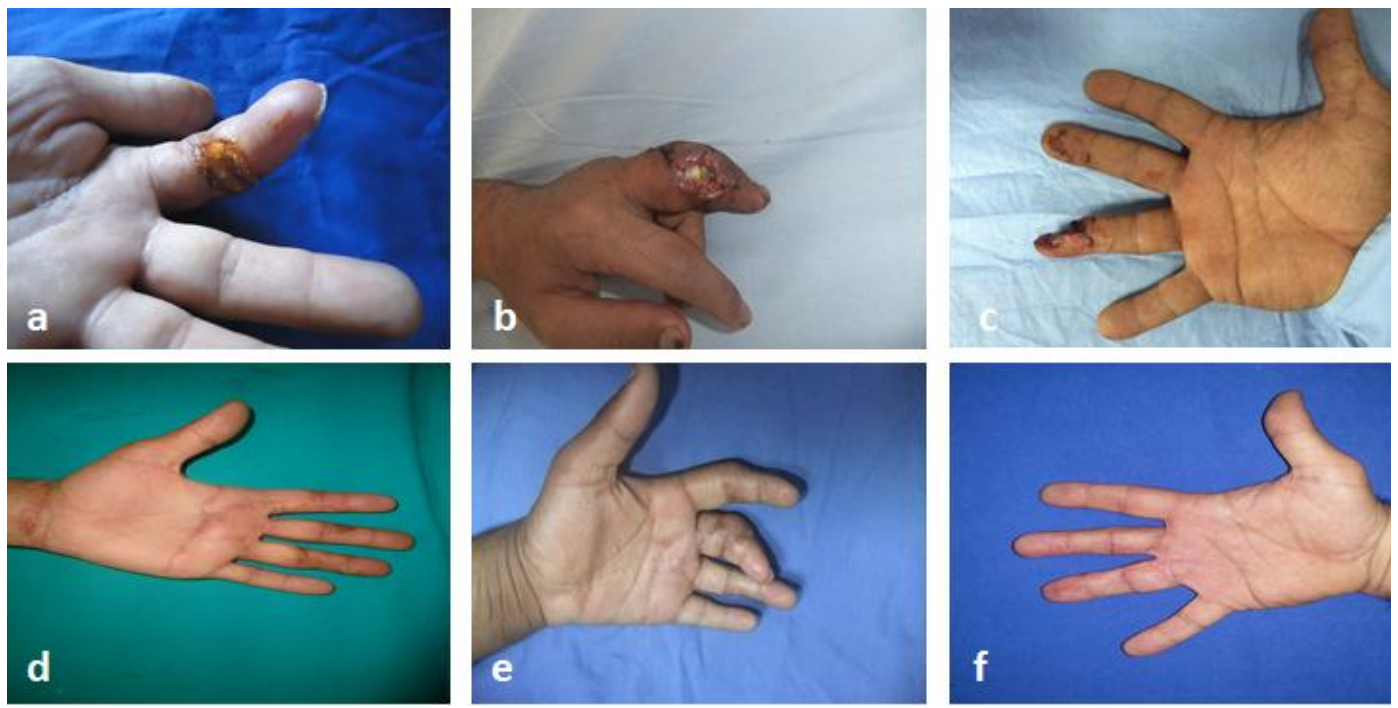

Figure 2. Reconstruction of different finger defect with littler flap a-c) Soft tissue defect examples for index, middle, ring fingers, respectively d-f) Post operative results of second, middle, ring finger flaps, respectively 


\section{CMJ Original Research December 2016, Volume: 38, Number: 4}

\section{RESULTS}

All flaps survived completely without partial or total necrosis. During the postoperative monitorization of flap, 3 (\%23) patients had problems related to venous insufficiency/congestion; flap circulation, however, recovered in all at follow-up. Wound infection was not observed. Donor-finger full-thickness skin grafting was successful in all cases. No major scar contractures were recorded in any patient.

At a mean follow-up of 12 months (range 9-16 months), the mean static 2PD and Semmes-Weinstein monofilament scores on the flaps were $8.6 \mathrm{~mm}$ (range, 7-11 $\mathrm{mm}$ ) and 4.15 (range, 3.61-4.56), respectively. Based on the modified American Society for Surgery of the Hand guidelines for stratification of s2PD, 12 (\% 92.3) of 13 flaps achieved good s2PD results and 1 (\%7.7) flaps obtained moderate 2PD results. According to the Cold Intolerance Severity Score, $11(\% 84.6)$ reconstructed fingers had no cold intolerance and $2(\%$ 16.4) experienced mild cold intolerance. Based on the VAS, 10 (\%77) fingers had no pain, and $3(\% 23)$ experienced mild pain. Based on the Michigan Hand Outcomes Questionnaire, 9 (\%69.2) patients were strongly satisfied (score 5) and $4(\% 30.8)$ were satisfied (score 4) with functional recovery of the reconstructed finger (Table 2).

Table 2. Questionaries and scores of the patients.

\begin{tabular}{lllllll}
\hline CASE & $\begin{array}{l}\text { ROM } \\
\text { (DIP/PIP) } \\
\text { (degrees) }\end{array}$ & $\begin{array}{l}\text { FLAP } \\
\text { S2PD (mm) } \\
\text { SWM }\end{array}$ & & CISS & Pain & $\begin{array}{l}\text { Appearance } \\
\text { (MHQ) }\end{array}$ \\
\hline $\mathbf{1}$ & $90 / 45$ & 7 & 3.61 & 0 & 0 & 5 \\
$\mathbf{2}$ & $100 / 55$ & 8 & 4.31 & 0 & 0 & 5 \\
$\mathbf{3}$ & $90 / 50$ & 7 & 4.31 & 20 & 4 & 4 \\
$\mathbf{4}$ & $110 / 60$ & 10 & 4.56 & 0 & 0 & 4 \\
$\mathbf{5}$ & $100 / 60$ & 9 & 4.31 & 0 & 0 & 5 \\
$\mathbf{6}$ & $100 / 60$ & 8 & 3.61 & 0 & 0 & 5 \\
$\mathbf{7}$ & $70 / 40$ & 9 & 4.31 & 0 & 0 & 5 \\
$\mathbf{8}$ & $90 / 55$ & 10 & 4.56 & 10 & 2 & 4 \\
$\mathbf{9}$ & $110 / 70$ & 10 & 4.31 & 0 & 2 & 5 \\
$\mathbf{1 0}$ & $90 / 50$ & 11 & 4.56 & 0 & 0 & 5 \\
$\mathbf{1 1}$ & $95 / 50$ & 7 & 3.61 & 0 & 0 & 5 \\
$\mathbf{1 2}$ & $100 / 50$ & 9 & 4.31 & 0 & 0 & 4 \\
$\mathbf{1 3}$ & $110 / 50$ & 8 & 3.61 & 0 & 0 & 5 \\
\hline mean & & & & & & \\
\hline
\end{tabular}

2PD : 2-point discrimination test

SWM: Semmes-Weinstein Monofilament test

CISS: Cold intolerance severity score

On the donor sites, the mean static 2PD and Semmes-Weinstein monofilament scores were was $11.2 \mathrm{~mm}$ (range, 9-14 mm) and 4.35 (range, 4.17-4.56), respectively. 10 (\%77) donor fingers had no cold intolerance and $3(\% 23)$ experienced mild cold intolerance. According to the VAS, 10 (\%77) fingers had no pain on the donor sites, and $3(\% 23)$ experienced mild donor pain. The range of motion of the donor fingers was similar to that of the opposite sides (Table 3). 
Table 3. The range of motion of the donor and opposite fingers

\begin{tabular}{|c|c|c|c|c|c|c|}
\hline CASE & $\begin{array}{l}\text { ROM } \\
\text { (degre } \\
\text { Donor } \\
\text { Finger }\end{array}$ & pposite side & $\begin{array}{l}\mathbf{S} 2 \mathbf{P} \\
(\mathbf{m m}\end{array}$ & $\begin{array}{l}\text { ite } \\
\text { VM }\end{array}$ & CISS & Pain \\
\hline 1 & $60 / 100$ & $60 / 110$ & 10 & 4.17 & 0 & 0 \\
\hline 2 & $70 / 90$ & $75 / 95$ & 12 & 4.56 & 0 & 0 \\
\hline 3 & $80 / 100$ & $85 / 115$ & 11 & 4.17 & 10 & 2 \\
\hline 4 & $85 / 90$ & $90 / 95$ & 10 & 4.17 & 0 & 0 \\
\hline 5 & $70 / 95$ & $75 / 105$ & 13 & 4.56 & 0 & 0 \\
\hline 6 & $85 / 90$ & $90 / 115$ & 13 & 4.56 & 0 & 2 \\
\hline 7 & $75 / 100$ & $75 / 105$ & 12 & 4.17 & 0 & 0 \\
\hline 8 & $80 / 90$ & $90 / 95$ & 10 & 4.17 & 10 & 0 \\
\hline 9 & $80 / 95$ & $90 / 115$ & 9 & 4.17 & 0 & 0 \\
\hline 10 & $75 / 100$ & $75 / 105$ & 10 & 4.56 & 0 & 0 \\
\hline 11 & $85 / 90$ & $90 / 95$ & 13 & 4.56 & 10 & 2 \\
\hline 12 & $75 / 100$ & $85 / 105$ & 14 & 4.56 & 0 & 0 \\
\hline 13 & $75 / 90$ & $90 / 95$ & 9 & 4.17 & 0 & 0 \\
\hline mean & & & 11.2 & 4.35 & 2.3 & 0.4 \\
\hline
\end{tabular}

2PD : 2-point discrimination test

SWM: Semmes-Weinstein Monofilament test

CISS: Cold intolerance severity score

\section{DISCUSSION}

Many surgical techniques including homodigital, heterodigital, and microsurgical operations have been defined for the reconstruction of finger defects. Homodigital flaps are indicated for smaller defects.$^{7,8}$ Among these, the flag flap described by Iselin in 1973 for small-sized defects, and the palmar digital artery based lateral/palmar reverse flow island flap described by Oberlin in 1988 can solve problems in injured fingers. ${ }^{9-10}$ Their usage is limited in local transposition, rotation, and extension flaps. Some other options are axial pattern transposition flap, arterialized lateral finger flap, and homodigital subcutaneous flap, although the application of these flaps is also limited because there must be sufficient amount of tissue around the defect and they necessitate the sacrification of palmar digital artery. ${ }^{11-13}$ Moberg flap, one of the flaps used for thumb reconstruction, is used for defects smaller than $1.5 \mathrm{~cm}$ in diameter although it has certain disadvantages such as flexion contractures and joint stiffness. In larger defects, heterodigital flaps such as crossfinger flap and heterodigital neurovascular island flaps (Littler, Foucher flap etc.) are widely used ${ }^{14,15}$

Despite being one of the primary options for the reconstruction of especially the finger tip defects, cross-finger flap is not always feasible due to simultaneous injury to adjacent fingers or limited expected cosmetic harm in a single finger. ${ }^{16,17}$ Although the advantage of covering the existing defect particularly with cross-finger and interpolation flap, it has an important disadvantage of frozen joint as a result of finger immobilization for about 2 weeks, particularly in older patients.

The reconstruction of finger soft tissue defects is challenging in terms of functional and aesthetic outcomes. 
Abdominal interpolation or distant pedicled flaps are aesthetically flawed due to a bulkier tissue they create, when compared to heterodigital island flaps. They require more than one operation. Moreover, The free flaps are not an easy option, either, because the recipient vessels may be unhealthy due to surrounding infection or trauma. However, these techniques usually require a two-team approach, microsurgical technique, long operating time and carry a risk of anastomotic failure $^{18}$.

Among the heterodigital flap options, the Foucher flap, developed by Foucher and Braun in 1979, is a first dorsal metacarpal artery based neurovascular island flap, but it has important disadvantages such as a lower 2 point discrimination, cold intolerance, hyperesthesia, difficult cortical adaptation, and limited flap size. It is also probable that patients suffer a venous return anomaly due to pedicular dissections ${ }^{19-20}$

We preferred this flap because of a higher chance of survival than other conventional flaps, a lower rate of donor field comorbidities such as flexion contracture or joint stiffness, defect reconstruction without the need of finger shortening, and a shorter time to return to work after a single-stage procedure.

The most common postoperative complication of heterodigital neurovascular island flap is early venous congestion. Utmost care should be paid and the concomitant vein accompanying the artery should not be severed when dissecting the neurovascular pedicle. No flap loss was observed despite early venous congestion in 3 patients enrolled in the present study.

Rose modified the Littler neurovascular island flap to include only the digital artery and venae comitantes at its pedicle, preserving the digital nerve in the donor digit. ${ }^{20} \mathrm{We}$ haven't preferred this option because this procedure require to dissection pedicle so high risk for flap viability

Heterodigital neurovascular island flap was classically described by Littler for pulp defects of thumb. ${ }^{21}$ However, the feasibility of this flap in different finger defects was shown in our study. It was observed that this flap can be safely and readily used due to its longer rotation arch in volar or dorsal finger defects. The flap is reliable with consistent viability so that all Littler flaps survived completely. It provides similar tissue to that lost in terms of color and texture. The technique is simple and reproducible. Major disadvantage, resulting in sensory loss at the donor site but minimizing donor morbidity, the flap is harvested from the ulnar border, thus preserving the radial part that is in direct opposition with the thumb. ${ }^{22}$

However, a hypothenar island flap was preferred over Littler flap in fifth finger defects because of a simpler and more rapid dissection of a hypothenar island flap. Kojima et al. reported a clinical trial of vascularized flap transfers from the hypothenar eminence of the hand with successful results. ${ }^{23}$

The results of the donor and reconstructed fingers regarding range of motion showed that all patients achieved excellent or good results. The most important reason for the preference given to this flap in the reconstruction of finger defects is an excellent aesthetic outcome coupled with highly favorable joint mobility due to early mobilization as a result of a single-stage procedure. Therefore, patients returned to their activities after a short period of time. The absence of hypo-hyperesthesia problems in recipient finger is another advantage. Our opinion is that a littler flap should be used in different finger defects since it is highly useful and reliable in terms of flap complications and donor field morbidities.

\section{REFERENCES}

1. Teoh LC, Tay SC, Yong FC, Tan $\mathrm{SH}$, Khoo DB. Heterodigital arterialized flaps for large finger wounds: results and indications. Plast Reconstr Surg 2003; 111: 1905-13.

2. Puckett CL, Howard B, Concannon MJ. Primary closure of the donor site for the Littler neurovascular island flap transfer. Plast Reconstr Surg 1996; 97: 1062-4. 
3. Huang YC, Liu Y, Chen TH. Use of homodigital reverse island flaps for distal digital reconstruction. J Trauma 2010; 68: 429-33.

4. Delikonstantinou IP, Gravvanis AI, Dimitriou V, Zogogiannis I, Douma A, Tsoutsos DA. Foucher first dorsal metacarpal artery flap versus littler heterodigital neurovascular flap in resurfacing thumb pulp loss defects. Ann Plast Surg 2011; 67: 119-22.

5. Wong KH, Coert JH, Robinson PH, Meek MF. Comparison of assessment tools to score recovery of function after repair of traumatic lesions of the median nerve. Scand J Plast Reconstr Surg Hand Surg 2006; 40: 219-24.

6. Irwin MS, Gilbert SE, Terenghi G, Smith RW, Green CJ. Cold intolerance following peripheral nerve injury, Natural history and factors predicting severity of symptoms. J Hand Surg (Br) 1997; 22: 308-16.

7. Chung KC, Hamill JB, Walters MR, Hayward RA. The Michigan Hand Outcomes Questionnaire (MHQ): Assessment of responsiveness to clinical change. Ann Plast Surg 1999; 42: 619-22.

8. Eaton CJ, Lister GD. Treatment of skin and soft tissue loss of the thumb. Hand Clin 1992; 8: 71-97.

9. Iselin F. The flag flap. Plast Reconstr Surg 1973; 52: 374-77.

10. Oberlin C, Sarcy JJ, Alnot JY. Apport arteriel cutane de la main. Applications a la realisations des lambeaux en ilot. Ann Chir Main 1988; $7:$ 122-5.

11. Russell RC, Van Beek AL, Wavak P, Zook EG. Alternative hand flaps for amputations and digital defects. J Hand Surg (Am) 1981; 6: 399-405.

12. Fleegler EJ, Weinzweig N. The versatile axial pattern digital transposition flap. J Hand Surg (Am) 1988; 13A: 494-500.

13. Voch P, Merie M. The homodigital subcutaneous flap for cover of dorsal finger defect. Br J Plast Surg 1994; 47: 435-9.
14. Heitmann C, Levin LS. Alternatives to thumb replantation. Plast Reconstr Surg 2002; 110: 1492-503.

15. -Rose EH. Local arterialized island flap coverage of difficult hand defects preserving donor digit sensibility. Plast Reconstr Surg 1983; 72: 848-58.

16. Atasoy E. Reversed cross finger subcutaneous flap. J Hand Surg (Am) 1982; 7: 481-3.

17. Edgerton BW. Dorsal cross finger flaps. In: Strauch B, Vasconez LD, Hall EJ, (eds.), Grabb's encyclopedia of flaps. Boston: Little, Brown, 1990, 905-9.

18. Iwasawa M, Ohtsuka Y, Kushima H, Kiyono M. Arterialised venous flaps from the thenar and hypothenar regions for repairing finger pulp tissue losses. Plast Reconstr Surg 1997; 99: 1765-70.

19. Ege A, Tuncay I, Ercetin O. Foucher's first dorsal metacarpal artery flap for thumb reconstruction: evaluation of 21 cases. Isr Med Assoc J 2002; 4: 4213.

20. Rose EH: Island arterial finger $\mathrm{fl}$ aps in hand reconstruction. In: Gilbert A, Masquelet AC, Hentz VR (eds.), Pedicle Flaps of the Upper Limb: Vascular Anatomy, Surgical Technique, and Current Indications. London: Martin Dunitz, 1992; 13946.

21. Xarchas KC, Tilkeridis KE, Pelekas SI, Kazakos KJ, Kakagia DD, Verettas DA. Littler's flap revisited: an anatomic study, literature review, and clinical experience in the reconstruction of large thumb-pulp defects. Med Sci Monit 2008; 14: CR568-73.

22. Hashem AM. Salvage of degloved digits with heterodigital flaps and full thickness skin grafts. Ann Plast Surg. 2010; 64: 155-8.

23. Omokawa S, Yajima H, Inada $Y$, Fukui A, Tamai S. A Reverse hypothenar flap for finger reconstruction. Plast Reconstr Surg 2000; 106: 828-33. 